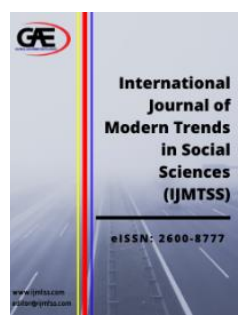

\author{
International Journal of Modern Trends in \\ Social Sciences (IJMTSS) \\ Journal Website: http://ijmtss.com/ \\ eISSN: $2600-8777$
}

\title{
THE CONCEPTUAL PAPER OF BUSINESS MODEL INNOVATION ENVIRONMENTAL FACTOR
}

\author{
Siti Som Husin ${ }^{1}$, Anis Amira Ab Rahman², Dzulkifli Mukhtar ${ }^{3}$ \\ $1 \quad$ Faculty of Business \& Entrepreneurship, Universiti Malaysia Kelantan, Malaysia \\ Email: som.a18e004f@siswa.umk.edu.my \\ 2 Faculty of Business \& Entrepreneurship, Universiti Malaysia Kelantan, Malaysia \\ Email: anisamira@umk.edu.my \\ 3 Faculty of Business \& Entrepreneurship, Universiti Malaysia Kelantan, Malaysia \\ Email: dzulkifli@umk.edu.my \\ Corresponding
}

\section{Article Info:}

\section{Article history:}

Received date: 23.12 .2019

Revised date: 08.04.2020

Accepted date: 14.06 .2020

Published date: 15.06 .2020

\section{To cite this document:}

Husin, S.S. Ab Rahman A.A. \& Mukhtar, D. (2020). The Conceptual Paper of Business Model Innovation Environmental Factor. International Journal of Modern Trends in Social Sciences, 3 (12), 82-88.

DOI: $10.35631 /$ IJMTSS. 312008

\begin{abstract}
:
This study draws the themes on environmental factors from two prominent authors in the business model innovation field, Allan Afuah and Alexander Osterwalder, with partner Yves Pigneur. This study reveals that both models have the same concept, even though the arrangement of the process is vice versa. This paper aims to reveal the environmental factors that contribute to a business model innovation. Evidence has shown that the entrepreneur and organization lead to creating the environmental factors in achieving a complete ecosystem in business model innovation. A lack of models and theories in business model innovation studies has led to this study to develop a model based on the entrepreneurship field. Therefore, this study reveals the environmental factors that contribute to the emerging business model innovation. The findings from this study results in a combination of these factors which are categorized based on the current situation. This study is expected to give understanding and knowledge to academicians and will be helpful to practitioners to create and apply a real business model innovation in various industries.
\end{abstract}

Keywords:

Business Model Innovation, Environmental, Model, Innovation

\section{Introduction}

Business model innovation (BMI) is a principle that organizations innovate by extending their internal capabilities and resources to increase profit (Zott and Amit, 2010). Previously, Reinmoeller and Van Baardwijk (2005) stated that business model innovation is about 
innovation strategies that can be identified by knowledge management, exploration, cooperation, and entrepreneurship. In contrast, Chesbrough (2010) defined that technology advancements force an organization to change immensely. It is shown that technology is an important element that leads to innovation and able to lead to success (Carayannis, Sindakis \& Walter; 2015).

Nevertheless, this study found that not all organizations are suitable to implement the technology because of the nature of the business itself. Business model innovation has three elements, namely entrepreneur, organization, and environmental (Husin, Rahman \& Razak, 2018). However, evidence shows a lack of comprehensiveness and a structure model that is able to show these three elements while this study only focuses on the environmental element (Iqbal, Khan, Bashir \& Senin, 2015; Gassman, Frankenberger \& Sauer, 2017). Developing a good understanding of these three elements leads to the organization becoming more reliable and more competitive, as confirmed by Osterwalder and Pigneur (2010). This study focused on the models by Afuah (2014) and Osterwalder and partner Pigneur (2010) to reveal the environmental factors that contribute to business model innovation.

\section{Literature Review}

\section{A Business Model Innovation Environment by Afuah}

This study found that the basics of business model innovation by Afuah (2014) need to be understood through these four capabilities: a) market segments, b) revenue model, c) growth model, and d) customer value proposition (Figure 1: A Business Model Innovation External Environmental).

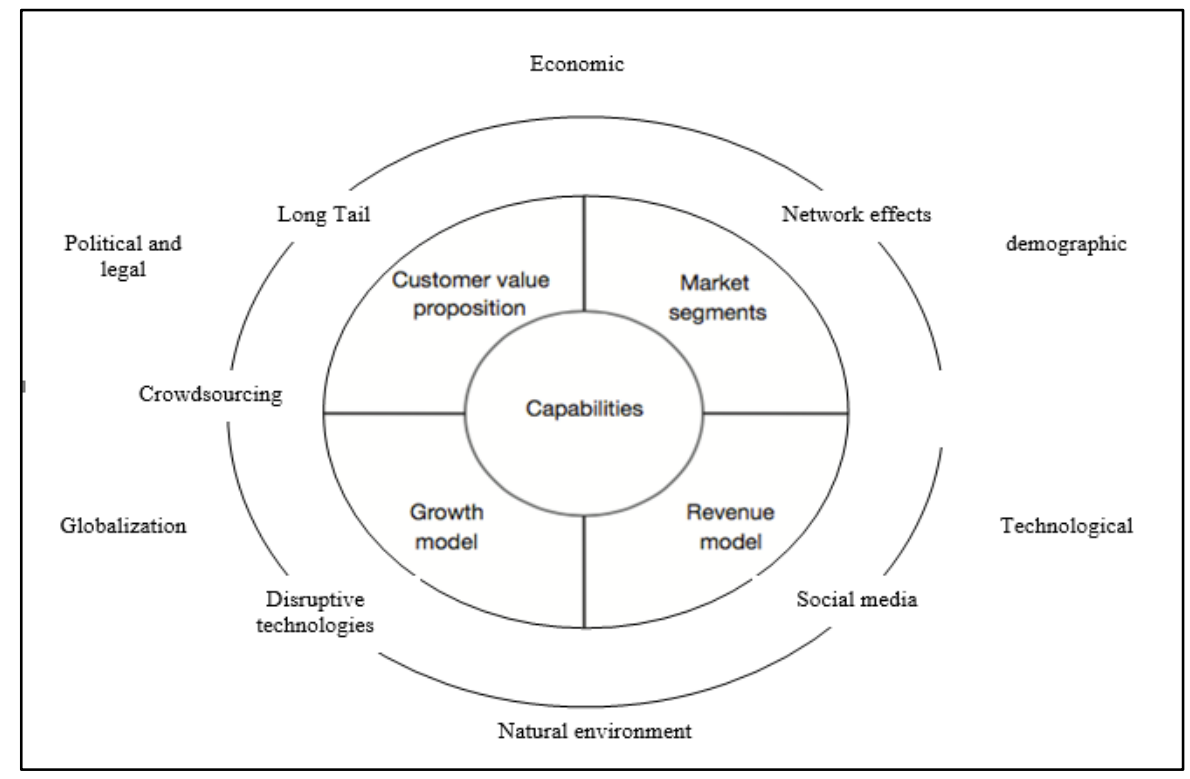

Figure 1: A Business Model Innovation External Environment

Source: (Afuah, 2014; pg. 16)

The problem with the business model was many organizations and entrepreneurs did not implement it because of a lack of understanding and knowledge (Joakim \& Magnum, 2013; Sabrina \& Speith, 2013; Osterwalder, Yves \& Christopher, 2015; Jones \& Pimdee, 2017). This can cause businesses and entrepreneurs to fail to visualize and make a decision about business models (Afuah, 2014). Afuah (2014) identified the suppliers, customers, complementors, Copyright (C) GLOBAL ACADEMIC EXCELLENCE (M) SDN BHD - All rights reserved 
competitors, substitutes, and other organizations that a business dealing needs to compete and create value to create profit (Figure 1). Political/legal, economic, social/demographic, technological and natural environment are defined as a macro environment (Afuah, 2014).

Typically, an organization will apply a business model innovation when they want to overcome the chances and at the same time, take for granted the environmental challenges (Afuah, 2014). Evidence has shown that the chances and challenges in the external environment factor come from some disruptive technologies; with less-is-more innovation, crowdsourcing, social media, the long tail, and government regulations (Afuah, 2014). Afuah (2014) highlights that the process of identifying the environmental factors can be created in two situations; the existing business model and non-existing business model are still accepted.

\section{A Business Model Environment Canvas by Osterwalder \& Pigneur}

The business model innovation environment canvas is recommended for the four main areas in the environmental factor: a) market forces, b) macro-economic forces, c) industry forces, and d) key trends (Figure 2: A Business Model Environment Canvas).

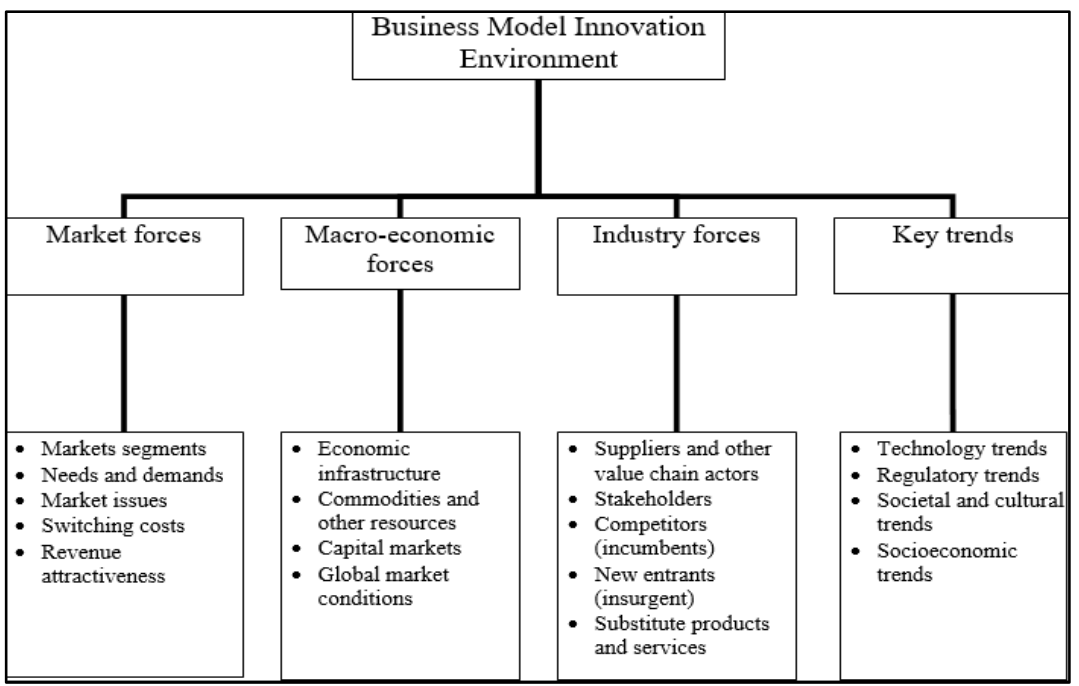

Figure 2: A Business Model Environment Canvas

Source: (Osterwalder \& Pigneur, 2010; pg. 201)

This study found that the business model by Osterwalder and Pigneur is designed to perform in specific main areas that are able to understand the changes happening in the environmental factor to help businesses redesign themselves to be flexible based on the chances and challenges that are happening (Osterwalder \& Pigneur, 2010). The model is named the business model environment canvas. This study found that it is a business model innovation because the external environmental factors can be added at the 'design space' by adapting design drivers such as new customer needs or new technologies and design constraints such as regulatory trends or dominant competitors (Osterwalder \& Pigneur, 2010). Osterwalder and Pigneur $(2010 ; 2015)$ highlight that mapping the environmental factors is able to identify and prepare an organization's market analysis for future trends of chances and challenges.

Based on the two models selected, this study found that the environmental factors in business model innovation can be divided into four domains: a) key trends, b) market segments, c) globalization, and d) natural. The domains consist of a theme that reveals the factors based on 
the business model innovation process (Geissdoerfer 2019) (Figure 1 and Figure 2). Based on Tables 1 and 2, the themes have been assigned to the authors' standpoints. The standpoint of the authors was not declared to the process steps. Geissdoerfer (2019) showed that there are a variety of process steps in business model innovation and the process steps can be divided into three broad phases: a) an idea or conceptualisation, b) design and experimentation, and c) implementation phase. This study found that the flow of the process steps depends mostly on the industry and critical events to rearrange the themes accordingly.

\section{Method}

The review process in this article has gone through five stages. Firstly, this study identified the existing models in the business model innovation literature. Secondly, this study selected models that have an environmental factor. Thirdly, models that have additional factors such as entrepreneurial and organizational factors were eliminated. Fourthly, this study was analysed by comparing and reorganising the themes based on the domains in the existing models. Finally, this study develops a model that is able to monitor the challenges and existing issues on business model innovation during the growth stages.

\section{Review Findings}

The purpose of this study is to understand the environmental factors in business model innovation. Previous research by many scholars mostly faced a problem in choosing the existing models in business model innovation because of the limitation of existing models and theories that are able to show all the main factors, such as entrepreneur, organization, and environment. Based on Afuah (2014) and Osterwalder and Pigneur (2010), this study presents the outcome in Table 1. This study has identified four domains of the environmental factors that contribute to business model innovation: a) key trends, b) market segments, c) globalization, and d) natural. The findings of this conceptual paper are limited to identifying the environmental factors based on two models by prominent authors. The combination of these two models helps this study develop the listed environmental factors that are able to contribute to a successful business model innovation (Table 1).

Table 1: Environmental Factors in Business Model Innovation Environmental factors in business model innovation

\begin{tabular}{|c|c|c|c|}
\hline Key Trends & Market segments & Globalization & Natural \\
\hline Regulatory trends & Needs \& demands & $\begin{array}{l}\text { Global market } \\
\text { conditions }\end{array}$ & $\begin{array}{c}\text { Substitute products } \\
\& \text { services }\end{array}$ \\
\hline $\begin{array}{l}\text { Societal, cultural } \\
\text { and demographic } \\
\text { trends }\end{array}$ & $\begin{array}{l}\text { Market issues: } \\
\text { • Long-tail }\end{array}$ & Capital markets & $\begin{array}{l}\text { Customer value } \\
\text { proposition }\end{array}$ \\
\hline $\begin{array}{l}\text { Socio-economic } \\
\text { trends }\end{array}$ & Switching costs & $\begin{array}{l}\text { Economic } \\
\text { infrastructure }\end{array}$ & \multirow{3}{*}{$\begin{array}{l}\text { Network effects: } \\
\text { - Suppliers \& other } \\
\text { value chain actors } \\
\text { - Stakeholders } \\
\text { - Competitors } \\
\text { - New entrants }\end{array}$} \\
\hline \multirow{2}{*}{$\begin{array}{l}\text { Technological } \\
\text { trends: } \\
\text { - Social media } \\
\text { • Disruptive } \\
\text { technologies } \\
\text { - Less is more } \\
\text { innovation }\end{array}$} & $\begin{array}{l}\text { Revenue model \& } \\
\text { attractiveness: } \\
\text { - Crowdsourcing }\end{array}$ & $\begin{array}{l}\text { Commodities \& other } \\
\text { resources }\end{array}$ & \\
\hline & Growth model & Political \& legal & \\
\hline
\end{tabular}

Sources: Afuah, 2014; Osterwalder \& Pigneur, 2010 
However, this study believes that not all the factors would appear in every business model innovation of each organization or industry. The differences and uniqueness of products and services that an organization deals with will lead to suitable environmental factors as well as the business model innovation itself. Based on critical trend factors, this study has located four elements such as regulatory trends, societal, cultural/demographic trends, socio-economic trends and technological trends (social media, disruptive technologies and less-is-more innovation) (Wirtz, Schilke \& Ullrich, 2010; Carrillo-Hermosilla, Del Gonzalez \& Konnola, 2009).

There are four elements in the market segment such as need and demands, market issues (long tail), revenue model and attractiveness (crowdsourcing), and growth model. Globalization factors have five elements, namely global market conditions, capital market, economic infrastructure, commodities/other resources and political/legal (Lee, Shin \& Park, 2012). Natural environment factors have three elements which are substitute products/services, customer value proposition and network effects (suppliers/other value chain actors, stakeholders, competitors, and new entrants).

\section{Discussion}

As mentioned earlier, the findings from this conceptual paper are limited to two prominent authors in the business model innovation field. The findings have identified the environmental factors in both models that have been used by many scholars to the emerged business model and the business model innovation based on the context of their studies. This study comes out with an environmental factor that can be divided into four cores: a) key trends, b) market segments, c) globalization, and d) natural. The key trends refer more to the tendency of people that can change based on socioeconomic, society, regulatory, cultural, demographic and innovation (something related to social media and technologies). It shows that the demography of the business itself can influence the business model innovation directly.

A market segment typically depends on the needs and demands of society. The market issue regarding long-tail and switching costs are more on the product involved compared to services. The revenue model and the attractiveness are slightly important depending on the phase of the business and growth to measure the sustained timeline in the industry. This study believes that globalization and natural elements do not influence business model innovation directly, but they are important to add depending on the network effects.

More importantly, this study has compiled all the factors and categorized them in the current situation based on the context of the study. This combination is ready to use and can be applied in any business or guideline as a start-up. Equally important, these environmental factors can be strengthened when combined with the entrepreneurial and organizational factors to complete the realistic business model innovation.

\section{Conclusion}

From the findings of this research, it can be concluded that the combination of two models can be merged to develop a new suitable model for many industries. There is a lack of models that are able to provide knowledge and understanding of SMEs and literature. This study agreed with Husin, Ab Rahman and Abdul Razak (2018) to implement the distinctive domain approach to reveal the phenomenon on business model innovation. The distinctive domain approach that aligns with the Schumpeter perspective is suitable for future research to develop exclusive findings. The domain permits this study to compare studies that lead to a less 
fragmented field and enable more robust knowledge accumulation within the field (Landstrom, 2020).

This study recommends future review in the areas that could widen the scope to include entrepreneurial research factors and organizational factors that contribute to business model innovation. Consideration of in-depth research to reveal entrepreneurial and organizational factors of business model innovation are still lacking, especially a model that is able to show all the three factors in realistic and flexible ways. Therefore, this will help future research to focus on entrepreneur and organization factors, especially in the entrepreneurship field. Finally, future research should aim to develop a complete ecosystem in business model innovation.

\section{References}

Afuah, A. (2014). Business model innovation: concepts, analysis, and cases: Routledge.

Carayannis, E. G. Sindakis, S. \& Walter, C. (2015). Business Model Innovation as Lever of Organizational Sustainability. Journal of Technology Transfer, 40(1), 85-104.

Carrillo-Hermosilla, J. del Gonzalez, P. R., \& Konnola, T. (2009). What is eco-innovation? Eco-innovation (pp. 6-27): Springer.

Chesbrough, H. (2010). Business Model Innovation: Opportunities and Barriers. Long Range Planning, 43, 9.

Frankenberger, K., Weiblen, T., Csik, M., \& Gassmann, O. (2013). The 4l-framework of business model innovation: a structured view on process phases and challenges. Journal of Product Development, 18, 22.

Gassman, O., Frankenberger, K. \& Sauer, R. (2017). A Primer on Theoretically Exploring the Field of Business Model Innovation.

Geissdoerfer, M. (2019). Sustainable business model innovation: Process, challenges and implementation.

Husin, S. S., Ab Rahman, A. A. \& Razak, A. A. (2018). A Review of Business Model Innovation Theories. The 6th International Seminar on Entrepreneurship and Business (ISEB), Hotel Perdana, Kota Bharu, Kelantan Malaysia.

Iqbal, A. M. Khan, A. S. Bashir, F. \& Senin, A. A. (2015). Evaluating National Innovation System of Malaysia Based on University-industry Research Collaboration: A System Thinking Approach. Journal of Asian Social Science, 11(13), 16.

Joakim, B., \& Magnus, H. (2013). Business model innovation - the challenges ahead. Product Development, 18(3/4), 13.

Jones, C., \& Pimdee, P. (2017). Innovative ideas: Thailand 4.0 and the fourth industrial revolution. Asian International Journal of Social Sciences, 17(1), 32.

Landstrom, H. (2020). The Evolution of Entrepreneurship as a Scholarly Field. Foundations and Trends® in Entrepreneurship, 16(2), 65-243.

Lee, Y. Shin, J. \& Park, Y. (2012). The changing pattern of SME's innovativeness through business model globalization. Technological Forecasting and Social Change, 79(5), 832-842.

Osterwalder, A. \& Pigneur, Y. (2010). Business model generation: a handbook for visionaries, game-changers, and challengers: John Wiley \& Sons.

Osterwalder, A. Pigneur, Y. \& Tucci, C. L. (2015). Clarifying Business Models: Origins, Present, and Future of the Concept.

Reinmoeller, P. \& Van Baardwijk, N. (2005). The link between diversity and resilience. Mit Sloan Management Review, 46(4), 61.

Sabrina, S. \& Patrick, S. (2013). Business Model Innovation: Towards an integrated future research agenda. International Journal of Innovation Management, 17(1), 34. 
Wirtz, B. W. Schilke, O. \& Ullrich, S. (2010). Strategic development of business models: implications of Web 2.0 for creating value on the internet. Long Range Planning, 43(23), 272-290. 